\title{
An Evaluation of Quantitative Easing Policy in England and Necessary Conditions for It Achievement
}

\author{
Danjuma, Naisla Hassan, Habakkuk Aboki, Sylvester, Umbugadu Aku \\ Department of General Studies and Pre-ND, Nasarawa state Polytechnic lafia. \\ Department of Accountancy, Nasarawa State Polytechnic, lafia Nasarawa State Nigeria.
}

\begin{abstract}
The credit crunch saw a number of innovations on monetary policy, the most notable of which was quantitative easing, whereby the central banks of a number countries purchase assets, mainly long term government bonds from private sectors. This research tends to explain how the bank of England implemented quantitative easing; it also gives justifications for recent innovation of the quantitative easing monetary policy. The monetary policies adopted by the Bank of England, European central bank and federal reserve of USA were all compare. Finally useful recommendations are provided to further help in the implementation of the quantitative easing policy in UK and any other economy.
\end{abstract}

Key words: Quantitative easing, monetary policy, credit crunch, government bonds, interest rate.

\section{Introduction}

Quantitative easing is a monetary policy whereby the central banks of a number of countries purchase assets, mainly long term government bonds from private sectors. This policy is geared towards releasing more funds into the economy thereby increasing the supply of money in the economy. The research evaluates the implementation of the quantitative easing monetary policy used by the Bank of England. Some economic justification of quantitative easing by Bank of England include; low spending in the economy, reduction in purchasing across the board and deflation in the economy. Though the global macroeconomic conditions for adoption of quantitative easing policy comprise high level of unemployment, housing boom and bust, fall in stock prices and failing of financial institutions. The monetary policies of England, controlled by Bank of England, USA controlled by Federal Reserve in US and European Union (EU) controlled by European Central Bank were all compared. However, the quantitative easing policy had numbers of criticism surrounding its implementation which comprises liquidity trap, which is low interest rate for example, as low as $0.5 \%$ interest rate England have failed to see rapid increase in aggregate demand, mortgage criteria have became much stricter, there was funding gap in commercial banks. Conclusively, some usable meaningful recommendations were suggested for the England economy and others who have a tendency to put into practice quantitative easing monetary policy. Such as, central bank should concentrate on the indigenous firms than the multinational corporation. The later will repatriate such money to their headquarters instead of using them within their host economy. Money looters politicians should be properly monitored to ensure money are not deviated for their selfish purpose. The money gotten from the sales of government bonds through quantitative easing should be use for what it was made for. Enough time should be allowed for the money eased into the economy to circulate, because the economy crunch does not just occur in a year therefore money eased will also take time to circulate into the economy to bring the economy back to it position.

\section{Implementation and economic justification of quantitative easing by the Bank of England}

To properly explain how the bank of England has implemented quantitative easing, and state its economic justification, it is pertinent to know briefly what quantitative easing is all about.

Quantitative easy refers to how the central bank increases the money supply and uses electronically created funds to buy government bonds, assets or other securities, pettinger (2010). It does not involve printing more bank notes. The assets purchase programme is not about giving money to banks. Rather, the policy is designed to circumvent the banking system. The Bank of England electronically creates new money and uses it to purchases gilts (bonds) from private investors, such as insurance companies and pension funds. Because this money yields a low return, the investors tend to use it to purchase other assets, such as corporate bonds and shares.

The Bank of England through the monetary policy committee (MPC) has been purchasing assets financed by new money that the bank creates electronically, often known as quantitative easing. This policy is designed to inject money directly into the economy, Bank of England (A). This is in response to a sharp fall in demand as business and consumers reduce their spending. In short there is not enough money in the economy. For the bank of England to inject money through the monetary policy committee into the economy, in March 2009 , they first announced the reduction of the bank rate to $0.5 \%$ (Fender 2012). 
Between March 2009 and January 2010, the monetary policy committee authorised the purchase of £200 billion worth of assets, mostly gilts, UK government debt. The MPC voted to begin a further purchase of £75 billion in October 2011, and subsequently, at their meeting in February 2012, the committee decided to purchase $£ 50$ billion to bring the total asset purchases to $£ 325$ billion.

However, the economic justification for implementing the monetary policy was thus: Low spending in the economy - Bank of England (2012) confirms that spending in the economy slowed in the later part of 2008 and 2009 as a global recession gathered pace. This threatened a downward spiral through a combination of contracting real output and price deflation. The MPC responded decisively, cutting Bank rate from 5\% to $0.5 \%$. its lowest level in just five months in order to support activity and thus reduce the risk of inflation falling below the $2.0 \%$ target in the medium term.

The inflation target of $2 \%$ is expressed in terms of an annual rate of inflation based on the consumer prices index (CPI). The remit is not to achieve the lowest possible inflation rate. Inflation below the target of $2 \%$ is judged to be just as certain as inflation above the target. The inflation target is therefore symmetrical.

Reduction in purchasing across the board - this activity resulted in the accumulation of inventory, which led to an increase in the unemployment rate, and of course even less spending to alleviate the economic situation.

Deflation in the economy - there was a general decline in prices. This is often caused by a reduction in the money supply or credits. It is also a decrease in government personal or investment spending, e.g. Japan had a period of deflation lasting for decades in the early 1990s, with zero interest rate policy which ended in 2006 in an effort to stimulate inflation.

\section{The global macroeconomic conditions for adoption of quantitative Easing policy}

The macroeconomic conditions necessitating the adopting of this type of monetary policy include:

High level of unemployment- the economy has faced serious challenges of unemployment. Economics Helps (2009), agrees that the job market unfortunately remains very weak, a large number of people can find only part time work, and a substantial fraction of the unemployed have been out of work. The heavy costs of unemployment include intense strains on family finances, more foreclosures and the loss of job skills. The chart below further explained the rate of unemployment prior to the credit crunch period. The unemployment rate was as high as around 10\% between 2008 -2009 while the real GDP rate was falling.

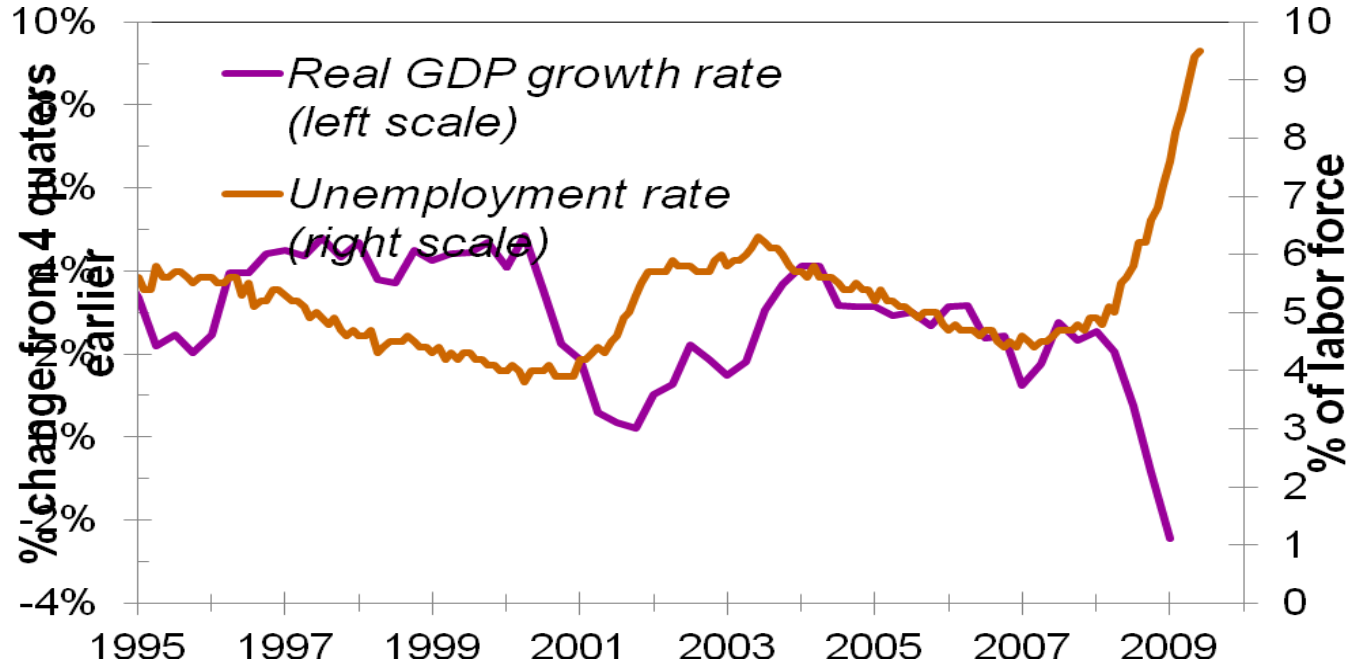

Source: Mankiw (2009)

Housing boom and bust - in late 1990, and early 2000, there was a housing boom. UK housing prices rose much faster than inflation until 2007, when the credit crunch completely changes the nature of the mortgage market. As mortgages were withdrawn, house prices started to fall. But, because mortgage affordability was stretched, people were not able to save the new size of deposits. The falling price has played a crucial role in affecting consumer spending and consumer confidence. It has directly led to job losses in construction and estate agents, (Greater London Authority 2008). This can be further explained in the graph below. The graph compares the boom-bust with the counterfactual period. That is a period where there is no boom and no bust. 
The boom- bust graph compared with the counterfactual

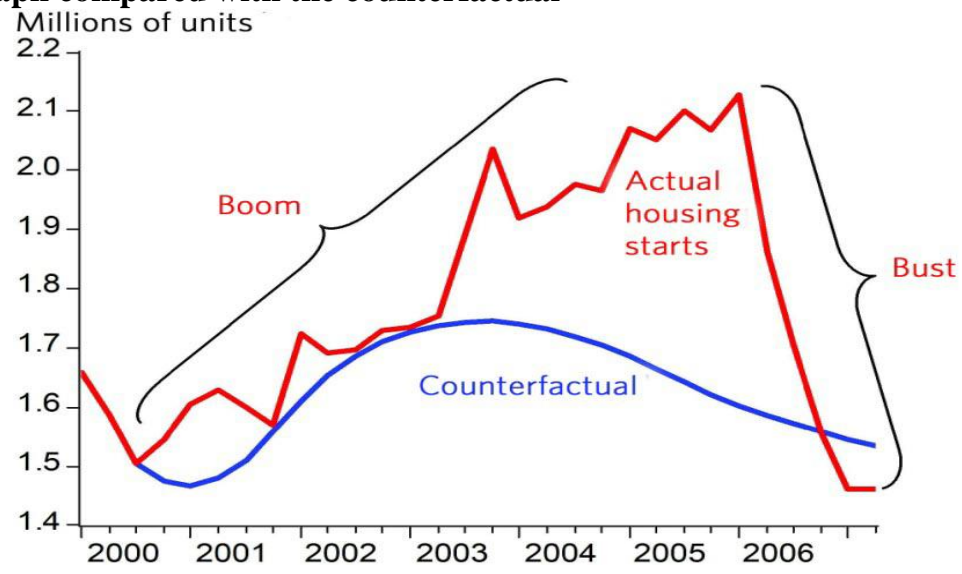

Failing financial institution- A stable financial system inspires the confidence of business, investors and consumers, and underpins vital economic activity. This is why the government has committed to introducing a new regulatory system in the UK, which will be better equipped to identify and deal with potential risks to the system in the future, HM Treasury (nd). In recent years, the financial agenda has been dominated by the consequences of the global financial crisis that began in 2007. In UK; the crisis involved a run on a high-street bank as well as the part-nationalization of two of the largest banks in the world.

Fall in stock prices - falling share prices can undermine business and eventually consumer confidence. Falling stock markets reduce the scope for firms borrowing money. Therefore, they may reduce their investment spending which impacts on the economy (Pettinger 2007). However, the financial crisis cost British households 1.9 trillion pounds of their wealth since July 2007, (Finance helper nd). With the property market falling to a slump and the economy mired in a recession forecast by the government to be the worst since World War II, the number of millionaires may keep falling this year. The chart below further explains how the Barclays share price fell drastically. From as high as $£ 800$ down to $£ 200$, these really affected many investors in the economy. The numerical numbers 1 to 14 explain its sequential dropping.

\section{The Investor (2008)}

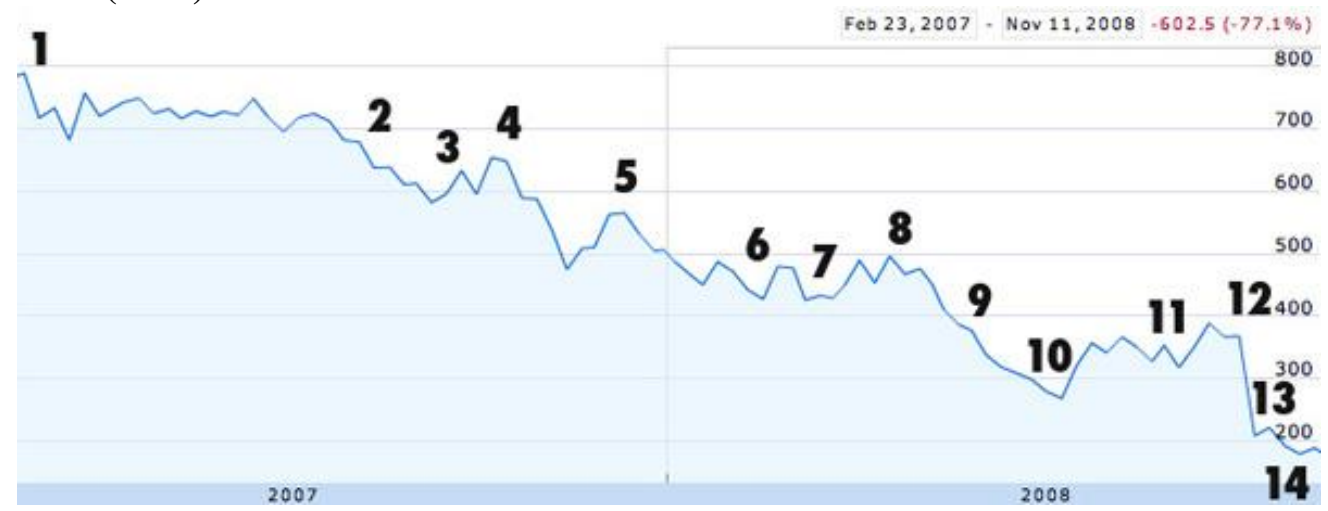

Going down: Barclays' share price from Feb '07 to Nov '08

\section{Whether or not same objective were achievable only by acting on the interest rate}

The same objectives by the adoption of quantitative easing were achievable only by acting on the interest rate. Bank of England (B) states that when the bank of England changes the official interest rate, it is attempting to influence the overall level of expenditure in the economy. When the amount of money spent grows more quickly than the volume of output, inflation is the result. In this way changes in interest rate are used to control inflation.

The Bank of England set an interest rate at which it lends to financial institutions. This interest rate then affects the whole range of interest rate set by commercial banks, building societies and other institutions for their own savers and borrowers. It also tends to affect the price of financial assets, such as bonds and shares, and the exchange rate which affect consumers and business demand in a variety of ways. 
A reduction in interest rates makes savings less attractive and borrowing more attractive, which stimulate spending. Lower interest rates can affect consumers and firms' cash -flow-a fall in interest rates reduces the income from savings and the interest payments due on loans. Borrowers tend to spend more of any extra money they have than lenders, so the net effect of lower interest rates through this cash flow channel is to encourage higher spending in aggregate. The opposite occurs when interest rates are increased.

Mankiw (2010, P98) and Young (1987) contended that money, price and interest rate are related in several ways. This relationship can be illustrated below.

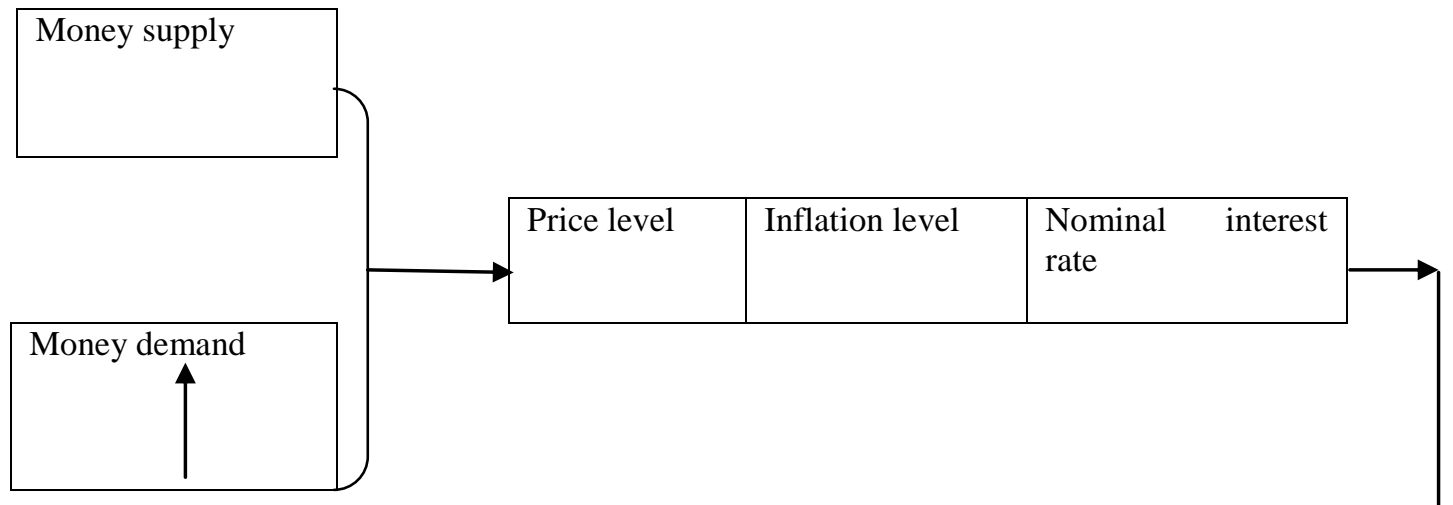

The above illustration explains the linkages among money, price and interest rates. Money Supply and money demand determined the price level. Changes in the price level determined the inflation rate. The inflation rates influence the nominal interest rate. Because the nominal interest rate is the cost of holding money, it may affect money demand.

LM curve can also be used to determine aggregate demand of money in the economy.

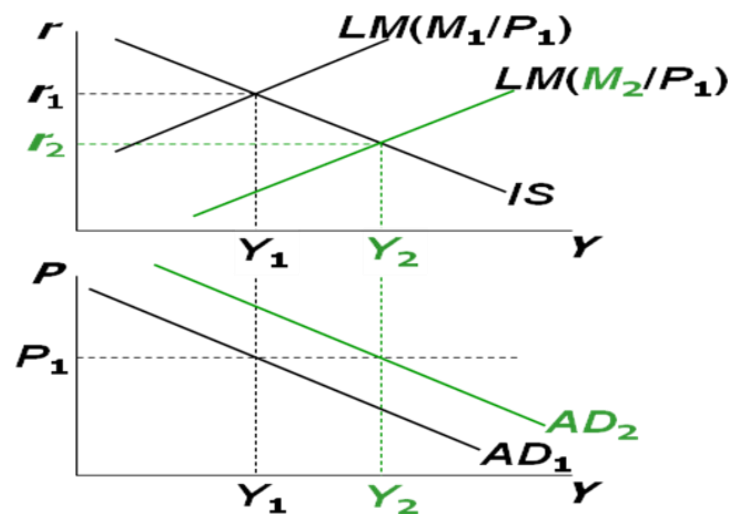

The curve above further explains how banks increase aggregate demand for money by acting on the interest rate. When banks increase the supply of money $(\mathrm{M})$, the LM shifts from LM (m1P1) to the right LM (m2p2), interest rate (r) will fall. Because households, investors or firms now have high income, as a result of fall in the interest rate, there would be an increase in the investment rate (I). The income at each value of $\mathrm{P}$ would be high and the aggregate demand would shift from AD1 to AD2 as shown in the graph above.

\section{Assessment of the theoretical justifications of quantitative easing}

As we have seen earlier, quantitative easing refers to as how the central bank increase in the money supply and using these electronically created funds to buy government bonds or other securities. E.g. Japan 2001, UK 2008 and US 2009 (Economics Help 2010). The theoretical justification for doing so was thus:

To increase bank liquidity - When commercial banks sell bonds to the central bank, they have an increase in their cash reserves. This increase in cash deposits should in theory encourage commercial banks to lend to business.

Through buying government bonds, the market price of bonds rises, leading to a production in long term interest rates. Lower interest rates should encourage greater economic activities in the economy. For instance, U.S. has cut interest rate from $1 \%$ to between 0 and $0.25 \%$, U.K. from $5 \%$ to $0.5 \%$ and Japan $0 \%$ and $0.1 \%$, (Financial Time 2008). However, there was greater interest in the Fed's plan of quantitative easing, buying assets such as treasury bonds and mortgage backed securities to effectively increase the money supply. 
Swedbank (2010,p4) states some justifications to include:

Quantitative easing help to reduce long term interest rates on the type of bonds that have been bought and others

It has given market a boost by adding liquidity during the crisis

High inflation expectations reduces real rates, which will potentially stimulate the economy

\section{Criticisms of the monetary policy}

In spite of the measure taken by the various governments to effectively curb the economic crisis by setting inflation target of $2.0 \%$, the policy faces numbers of criticisms. These include:

Interest rate lower and falling, with quantitative easing- Pettinger (2012) states that, for the past few years the economy have been experiencing an unusual combination of circumstances where many ordinary rules of economics are not occurring. The economy is currently experience a liquidity trap. A liquidity trap implies:

Low rates of interest failing to increase demand - Usually lower interest rate boost spending because it is cheaper to borrow, but in this current economic situation, even interest rates of $0.5 \%$ have failed to see rapid increase in aggregate demand. Low interest rates have failed to increase spending and investment because; confidence is very low. People do not want to invest when a double dip recession is forecast. People are reluctant to spend when they fear unemployment. House prices and other assets have fallen. This creates a negative wealth effect and discourages spending.

Banks are reluctant to lend because of their liquidity shortages - Although, it is in theory cheap to borrow, it is difficult to get a loan in the first place. For example mortgage criteria have become much stricter. Banks have funding gap - This funding gap explains why extra money supply from quantitative easing has not led to higher bank lending. They have been trying to improve their balance sheet. Although central bank base rates have fallen to $0.5 \%$ but many commercial banks have not passed these interest rates cut onto consumers.

Swedbank (2010) reveal that, the monetary base increases, but not the monetary supply, when the financial sector adjusts its balance sheets. This could change as the recovery continues. There are tools that in theory could be used to shrink balance sheets if needed e.g., if inflation expectations rise too quickly, but it can be hard to implement them at the right time and to the right degree.

A significant easing of U.S monetary would increase capital inflows to emerging economies, with the risk of financial stability. A significantly weaker dollar would adversely affect China's dollar reserves and force it to further diversify its currency portfolio, causing other currencies to appreciate. The risk of currency tensions increase when the fed eases monetary policy, also keeping in mind that key Asian currencies are not marketbased and are pegged to U.S. monetary policy.

\section{Debate on rules verses discretion in relation to quantitative easing}

Monetarists believe that money supply is the primary determinant of nominal GDP in the short run, and of the price level in the long-run, they think that control of the money should not be left to the discretion of central bankers. Monetarists believe in a set of rules, that, the Federal Reserve must follow. In particular monetarists prefer the money growth rule. The fed should be required to target the growth rate of money such that it equals the growth rate of real GDP, leaving the price level unchanged. If the economy is expected to grow at $2 \%$ in a given year, the fed should allow the money supply to increase by $2 \%$. Monetarist wish to take much of the discretionary power out of the hands of the fed so they cannot destabilised the economy (Griffiths and Wall 2012 and Alan 1997) while on the other hand, Keynesians refuses to go on at this proposed money growth rule. Keynesians believes that velocity is inherently unstable and they do not believe that markets adjust quickly to return to potential output. Therefore, Keynesians attach little or no significance to the quantitative theory of money. Because the economy is subject to deep swings and periodic instability, it is dangerous to take discretionary power away from the fed. The fed should have some lee way or discretion in conducting policy.

Relating this debate to the monetary policy implemented by UK, US, and Japan, it is apparently clear that quantitative easing does not follow the money growth rule. This is because the money growth rule believes that supply of money should not be left to the discretion of central bankers. That if an economy is expected to grow at $2 \%$ in a given year, the fed should allow the money supply to increase by $2 \%$. But the money supply is discretional. There has not been a given percentage of money targeted like what money growth rule stated. The bank of England continuous eases money as long as their expectation is not achieved.

Within March 2009 to January 2010, £200 billion worth of assets were purchased. £75 billion October 2011 and $£ 50$ billion February 2012 assets were purchased. The bank of England is still looking forth to eases more money into the economy, (Bank of England A).

\section{The risk of potential conflict between inflation targeting and quantitative easing}

Inflation expectation might expect to increase in response to the monetary stimulus associated with quantitative easing. Macallan and Taylor (2011), Fender (2012, P179) contended that the bank of England's 
monetary policy objective is to meet the government's inflation target. But the policy remits recognised that, in practice, unforeseen event are likely to cause inflation to depart from the target and that attempts to prevent such movement in inflation might generate undesirable volatility in output. Consequently, the MPC sets monetary policy so that inflation will return to target in the medium term.

The MPC is able to meet its monetary policy objective more easily when inflation expectations are credible by the monetary policy framework. If inflation expectations are anchored, in the sense that deviations in inflation from target are expected to be transitory, then companies and household are likely to set prices and wages in a way that will help to limit the extent to which any deviation in inflation persist. Conversely inflation expectations were to became less well anchored, deviation of inflation from target might trigger changes in price-setting and wage-setting behaviour that make those deviations more persistent. If inflation was to rise above target, that would mean that the MPC would have to tighten monetary policy by more than it otherwise would do to return inflation to target, other things being equal, which would result in a lower level of demand.

\section{The monetary policies adopted by Bank of England, Federal Reserve in the US and European Central Bank The Bank of England (BOE)}

The bank monetary policy objective is to deliver price stability, low inflation and subject to that to support Government economic objective such as growth and development. Price stability is defined by the government's inflation target of $2 \%$. The remit recognises the role of price stability in achieving economic stability, and in providing the right conditions for sustainable growth in output and employment. The government's inflation target is announced each year by the Chancellor of the Exchequer in the annual budget statement (Bank of England B).

The 1998 Bank of England act made the Bank independent to set interest rates. The Bank is accountable to parliament and the wider public.

If target is missed by more than $1 \%$ point on either side, that is, if annual rates of CPI inflation is more than $3 \%$ or less than $1 \%$, the governor of the Bank must write an open letter to the chancellor explaining the reason why inflation has increased or fallen and what the Bank purpose to do to ensure inflation comes back to target.

The monetary policy committee (MPC)

The Bank seeks to meet the inflation target by setting an interest rate. The level of interest rate is decided by a special committee, the monetary policy committee. The MPC consist of 9 members, 5 from the Bank of England, and 4 external members appointed by the chancellor. It is chair by the Bank of England. The MPC meets monthly for a two day. Decisions are made by a vote of the committee on a one vote basis, and the decision is announced the second day.

\section{Federal Reserve of US (Fed)}

The US congress established the statutory objectives for monetary policy as maximum employment, stable prices and moderate long-term interest rates in the Federal Reserve act (Federal Reserve 2012).

The Federal Open Market Committee (FOMC) is firmly committed to fulfilling this statutory mandate. In pursuing these objectives, the FOMC seeks to explain its monetary policy decisions to the public as clearly as possible. Clarity in policy communication increases the effectiveness of monetary policy and enhances transparency and accountability which are essential in a democratic society.

In January 2012, FOMC issued a statement on monetary policy strategy. Its noted on it statement that the committee judges that inflation at the rate of $2 \%$ is most consistence over the longer run with the federal reserve's statutory mandate. Communicating this inflation goal clearly helps keep longer-term inflation expectations firmly anchored, thereby fostering price stability and moderate long-time interest rates and enhancing the FOMC's ability to promote maximum employment.

\section{European Central Bank (ECB)}

The ECB is the central bank for Europe's single currency, the euro. The main risk is to maintain the euro purchasing power and thus price stability in the euro area. The euro area comprises the 17 European Union countries that have introduced the euro since 1999. The primary objective of the ECB's monetary policy is to maintain price stability. The ECB aims at inflation rate below, but close to $2 \%$ over medium term. This is laid down in the treaty on the functioning of the European Union Article 127(1). Without discrimination to the objectives of price stability, the Euro system shall also support the general economic policies in the union with the view of contributing to the achievement of the objectives of the union. These include full employment and balanced economic growth (European Central Bank nd)

The ECB general council comprises of the following;

The president

The vice president of the ECB 
The Governors of the national central banks NCB of the $27 \mathrm{EU}$ member states

However, the general council can be regarded as transitional body. It carries out the task taken over from the European monetary institute which the ECB is require to perform in stage three of the economic and monetary union on account of the fact that not all EU member states have adopted the euro yet.

\section{Comparison of Bank of England monetary policy with Federal Reserve of US and European Central Bank}

Having discussed the monetary policies of the three various banks above, their similarities can be explain below as follows.

Price stability- one of the common goal of these three banks is maintenance of price stability in their economies. Price stability is defined by the government as inflation target of $2.0 \%$, which is the banks keeping low rates of inflation. Since inflation lower real wages, Keynesians view inflation as the solution to involuntary unemployment. This is because unanticipated inflation leads to lender losses as the real interest rate will be lower than expected.

Maintain stable economic growth and development in their countries. Economic growth can enhance by investment in capital, such as more or better machine. A stable economic growth means smooth business cycle and no disruption to the economy. A low interest rate implies that firm can loan money to invest in their capital stock and pay less interest for it. Lowering the interest is therefore considered to encourage economic growth.

Achieve high employment. The monetary policy adopted by the Banks also emphasise on achievement of high employment for its citizens. The period between jobs when a worker is searching for or transitioning from one job to another is term frictional unemployment. For example, structural unemployment is a form of unemployment resulting from a mismatch between demand in the labour market and the skill and locations of the workers seeking employment.

Moderate long-term interest rates The mechanisms to move the market towards a target is generally to lend money in theoretical unlimited quantities, until the target market rate is sufficiently close to the target. During the recent financial crisis, Bank of Japan fixed interest rate at 0 to $0.1 \%$, Bank of England fixed interest rate at $0.5 \%$, Federal Reserve of US $0.25 \%$ and European Central Bank, at $1 \%$. These are all effort to encourage borrowing and spending in economy.

\section{Conclusion}

From the findings above, it shows that the monetary authorities have used quantitative easing as a tool of monetary policy instruments. Nevertheless, it seems sensible that they employ changes in their policy rate as their main instrument for the reasons discuss above. Quantitative easing has continued to be supplementary tool of monetary policy in circumstances when it is not possible to reduce the main instrument, the policy rate, when it is already as low as it can go. The policy was implemented to save the economy from it collapse as a result of the downturn. The policy was justifiable because of the lack of trust between the commercial banks and the household. Banks refused given out loan to household in other to consolidate its balance sheet. There was inadequate money in the economy. Although the aim of the central banks to eased liquidity through quantitative easing was not a complete success but it has reduce tension envisage by the monetary committees and even the masses.

\section{Recommendations}

Quantitative easing was a good measure undertaken by the MPC, but it was not a total success. I will therefore recommend that:

In implementing quantitative easing, central bank should concentrate on the indigenous firms than the multinational corporation. The later will repatriate such money to their headquarters instead of using them within their host economy.

Money looters politicians should be properly monitored to ensure money are not deviate for their selfish purpose. The money gotten from the sales of government bonds through quantitative easing should be use for what it was made for.

Enough time should be allowed for the money eased into the economy to circulate, because the economy crunch does not just occur in a year therefore money eased will also take time to circulate into the economy to bring the economy back to it position. 


\section{References}

[1]. Alan, G. 1997. Rules verses discretion: monetary policy. At 15 anniversary conference of the centre for economic policy research at Stanford University, Stanford California Sept. 5, 1997. (Online): Available at :< http://www.federalreserve.gov/boarddocs/speechs/1997/1997 0905.htm $>$
Bank of England 2012. Quantitative easing: injecting money into the economy. (Online): Available at: <http://www.bankofengland.ac.uk/education/document/targettwopointzero/t2p0-qe-supplement.pdf>

[3]. Bank of England (A) Quantitative easing: putting more money into the economy to boost spending. (Online): Available at: <http://www.bankofengland.co.uk/monetarypolicy/documents/pdf/qe-pamphlet $>$

[4]. Bank of England (B). Monetary policy framework. (Online): Available at: <http://www.bankofengland.co.uk/montarypolicy/pages/framework/ramework.aspx >

[5]. Economics Help 2009. Unemployment benefits and cost. (Online): Available at:

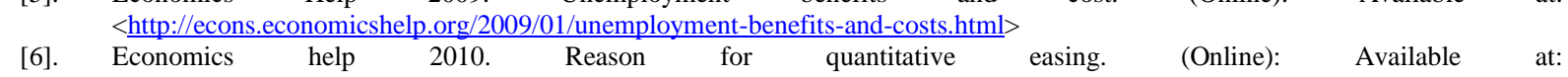
<http://www.economichelp.org/macroeconomic/macroessay/>

[7]. European central bank (nd). Monetary policy. (Online): Available at: 〈http://www.ecb.europa.eu/mopo/html/index.en.html>

[8]. Federal Reserve 2012. What are the Federal Reserve's objectives in conducting monetary policy. (Online): Available at: <http://www.federalreserve.gov/fags/money-12848.html>

[9]. Fender J. 2012. Monetary policy, John Wiley \& sons limited.

[10]. Financial Helper (nd) British millionaire's shrub shrivel by half on slump. (Online): Available at: < $\underline{\text { http://finhelper.com/britain's }}$ millionaire-club-shrivel-by-half-on-slump/>

[11]. Financial Time 2008. Quantitative easing from Japan. (Online): Available at:

[12]. Greater London Authority 2008. Credit crunch and property market. (Online): Available at: <http://www.londongov.uk/archive/mayor/economic-unit/docs/credit-crunch.pdf>

[13]. Griffiths, A. and Wall, S. 2011. Applied economics, twelve edition, Pearson education limited.

[14]. HM Treasury (nd) financial stability. (Online): Available at: 〈http://www.hm-treasury.gov.uk/fin-stability-index.html>

[15]. Macallan, C. And Taylor, T. 2011. Assessing risk to inflation from inflation expectations. Quarterly bulletin q2 p100. (Online): Available at: http://www.bankofengland.co.uk/publications/documents/quarterlybulletin/qb110201.pdf>

[16]. Mankiw, G. N. 2009. Macroeconomics, seventh edition, worth Palgrave Macmillan.

[17]. Mankiw, G. N. 2010. Macroeconomics, seventh edition $2^{\text {nd }}$ printing, worth Palgrave Macmillan.

[18]. Pettinger, T. 2007. What happened when stock market falls? (Online): Available at: <http://econ,economicshelp.org/2007/08/whathappened-when-stock-market-fall.html>

[19]. Pettinger, T, 2010. Quantitative easing definition: when to pursue quantitative easing; online): Available at: http://www.economicshelp.org/blog/1047/economics/quantitative-easing>

[20]. Pettinger, T. 2012. Explaining paradoxes of UK economy. (Online): Available at: <http://www.economichelp.org/blog/4900/economic/explaining-paradox-of-uk-economy>

[21]. Stock Market Share Prices 2012. Global wealth shuffle inevitable. (Online): Available at: <http://stockmarketshareprices.com/global-wealth-shuffle-inevitable/>

[22]. Swed-Bank 2010. Central bank faces difficult choices. (Online): Available at: http://www.swedbank.se/idc/group/@i/@sbg/@gs/@corpaff/@pubaff?document?publication/cid-168352.pdf>

[23]. The investor 2008. The Barclays share price and the credit crunch. (Online): Available at: <http://monevator.com/2008/11/13/thebarclays-share-price-and-the-credit-crunch/>

[24]. Young W. 1987. Interpreting Mr. Keynes: the IS-LM enigma, a maiden edition, polity press. 